\title{
Velvet Heart: Systemic Fungal Infection Accompanying with Cardiac Involvement and Review of the Literature
}

\section{Kadife Kalp: Kalp Tutulumunun Eşlik Ettiği Sistemik Mantar Enfeksiyonu ve Literatürün Gözden Geçirilmesi}

\author{
Sema Demirçin , , , Fatih Dirol ${ }^{3}$, Yaşar Mustafa Karagöz' , , , Kamuran Aylin Aksoy, \\ Derya Bulgur Kırbaș ${ }^{1}$, Pelin Göral ${ }^{1}$ \\ ${ }^{I}$ Akdeniz University Faculty of Medicine, Department of Forensic Medicine, Antalya \\ ${ }^{2}$ The Council of Forensic Medicine, Morgue Department of Antalya Regional Directorate, Antalya \\ ${ }^{3}$ The Council of Forensic Medicine, Branch Office of Antalya Regional Directorate, Antalya
}

\begin{abstract}
Injuries and intoxications are frequent cause of deaths in illicit drug users. Drug abuse is also associated with increase in infectious diseases and decreased level of immunity. Especially collective usage of syringes can be remarkably dangerous. It is difficult to diagnose the fungal infections in people whose immune systems are deficient and spreading of the pathogenic microorganisms through the bloodstream can lead to systemic infections which can cause rapid death.

In this article, a case of a 45 -year-old man is being presented who died due to illicit drug intoxication. Apparent cardiac involvement with systemic fungal infection has been determined at the autopsy. The case has been evaluated with the literature. The skin and cardiac findings of the case are both rare and educational. Besides, this report aims to draw attention to systemic infectious diseases that can be found at autopsies of persons who had used illicit drugs and it is intended to review the measures for the protection of the autopsy personnel.
\end{abstract}

Keywords: Heart; Drug Use; Fungal Infection; Autopsy; Infection Prevention; Protection.

\section{Introduction}

An estimated 183,000 (range: 95,000-226,000) drugrelated deaths were reported in 2012 according to the United Nations Office on Drugs and Crime (UNODC). That figure corresponds to a mortality rate of 40.0 (range: 20.8-49.3) deaths per million among the population aged between 15 and 64 years (1).

In Turkish Republic, according to 2013 Report of Monitoring Center for Drugs and Drug Addiction (TUBIM) which is being served as National Contact

Corresponding Author: Prof. Dr. Sema Demirçin

Akdeniz University, Faculty of Medicine, Department of Forensic Medicine,

Email:sdemircin@gmail.com

Arrived: 05.01.2016 Revised: 18.01.2016 Accepted: 25.01.2016

\section{Özet}

Madde bağımlılarında yaralanmalar ve zehirlenmeler sıklıkla görülen ölüm nedenleridir. Ayrıca madde bağımlılı̆̆ı, artmış enfeksiyon sıklı̆̆ ve azalmış immünite ile de ilişkilendirilmektedir. Özellikle ortak enjektör kullanımı kan yoluyla bulaşan enfeksiyonlar açısından ciddi tehlike yaratmaktadır. Bağışıklık sistemi yetersiz olan kişilerde, mantar enfeksiyonlarının teşhisi güç olabilmekte ve etkenin kan dolaşımı ile yayılımı, hızla ölüme neden olan sistemik enfeksiyona yol açabilmektedir. Olgularda nadiren kalp tutulumu da görülebilmektedir.

$\mathrm{Bu}$ sunumda; uyutucu ve uyuşturucu madde zehirlenmesine bağl1 ölen 45 yaşında erkek olgu aktarılmaktadır. Otopside belirgin kalp tutulumu gösteren sistemik mantar enfeksiyonu saptanmıştır. Olgu, kaynaklar eşliğinde değerlendirilmiştir. Olguya ait cilt ve kalp bulguları hem ender rastlanan hem de eğitici nitelikte bulgulardır. Bunların yanında makale, madde bağımlılarının otopsilerinde rastlanabilecek sistemik enfeksiyon hastalıklarına dikkati çekmeyi ve otopsi ekibinin korunmasına yönelik önlemleri gözden geçirmeyi amaçlamaktadır.

Anahtar Kelimeler: Kalp; Madde Kullanımı; Mantar Enfeksiyonu; Otopsi; Enfeksiyon Önlemleri; Korunma.
Point of European Monitoring Centre for Drugs and Drug Addiction (EMCDDA), deaths associated with illicit drug use have been identified directly in 162 cases and indirectly in 163 cases in 2012 (2).

According to the data commonly provided by The United Nations Program on HIV/AIDS (UNAIDS), The World Bank and The World Health Organization (WHO), it is assumed that there are 12.7 million (range: 8.9 million-22.4 million) intravenous illicit drug users all over the world. That corresponds to a prevalence of 0.27 per cent (range: $0.19-0.48$ percent) of the population aged between 15 and 64 (1).

Among illicit drug users, the most common causes of deaths are traumatic reasons and intoxications caused by used drug itself or its contaminants and fur- 
thermore the risk of premature death because of both acute and chronic diseases, it is more prevalent in intravenous illicit drug users than others (3). In these people, diseases linked to sharing of syringes or needles, the human immunodeficiency virus (HIV), hepatitis $\mathrm{C}$ virus (HCV), hepatitis B virus (HBV) and related diseases are considered as endemic and to be a major cause of morbidity and mortality all over the world (4). In people having risk factors such as this kind of illicit drug use and a suppressed immune system or immune system failure, disseminated fungal infections are usually observed (5).

In this article, the case died due to intoxication of intravenous illicit drug use and his findings of systemic fungal infection which are diagnosed at autopsy is being presented in the light of related literature. The risks which autopsy personnel are exposed to and infection prevention precautions are also reviewed. We also intended to draw attention to prevalence and danger of intravenous illicit drug use and its jeopardy.

\section{Case}

Forty-five years old male was found dead in his secure home. Deceased's relatives verbally expressed that he had used to illicit drug (with history of syringe sharing) and had HIV infection.

External examination revealed bluish-green ecchymosis like lesions on the skin with hard nodules under these skin surfaces were seen on the both flexor and extensor sides of right forearm, right elbow and bilateral thighs and scars in different wound ages due to former intravenous illicit drug injection on left antecubital fossa, both groins and upper front thighs.

Internal examination (body cavities) revealed that there was white matte view like frosted glass on the dura mater. Approximately $500 \mathrm{cc}$ reddish free fluid accumulation was seen in right cavity of the chest. There were fibrinous pleural adhesions between the lobes of both lungs and between the lungs and internal side of chest wall and changes are noted towards to green in color as general and an infectious view on tissues.

Inner side of the pericardium was completely in villus-like appearance, it was covered by reticulated red fibrin extensions. The outer surface of the heart was $0.2-0.3$ $\mathrm{cm}$ in thickness and had red velvet like view with fine fibrin extensions (Picture 1-2).

There were dirty reddish free fluid and fibrin extensions also in abdominal cavity. The view of surface and the sections of both kidneys were greenish in color and an infected view.

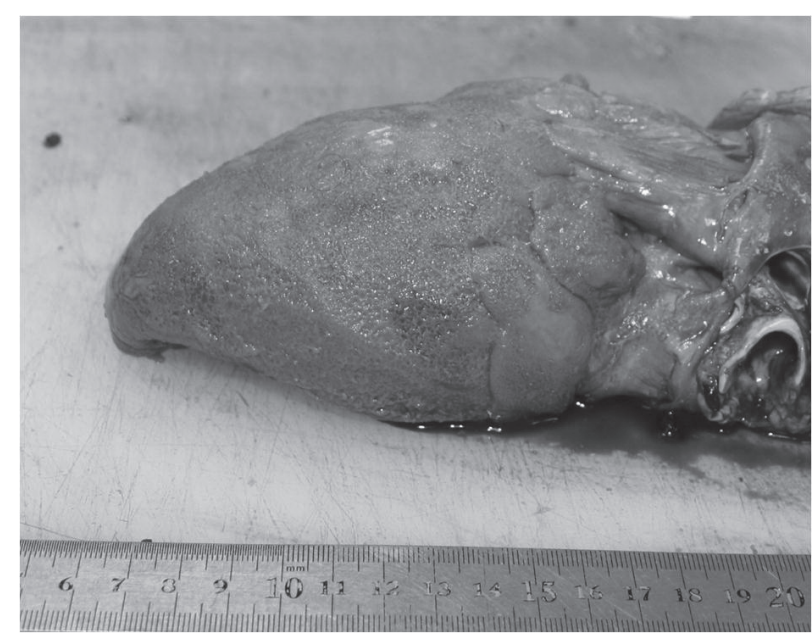

Picture 1. Velvet-like appearance with fibrinous infiltration on the upper surfaces of the heart.

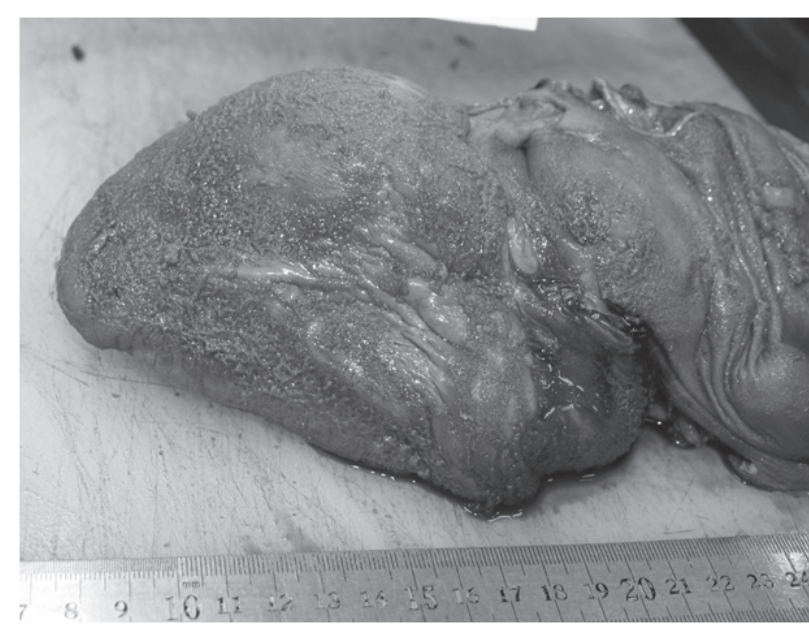

Picture 2. Velvet-like appearance with fibrinous infiltration on the inferior surfaces of the heart and pericardium.

\subsection{Histopathological Findings}

Brain and cerebellum; Congestion, perivascular edema, petechial microhemorrhages.

Dura mater; Extravasated erythrocytes which are lytic but with clear cytoplasmic border and their pooling in subdural cavity, presence of several hyphae, acute severe neutrophilic inflammation, areolar fibrin accumulation, hyphae ramification in some vessels, thrombi which are formed by neutrophils, erythrocytes and fibrin, focal granulomas formed by separated lymphocytes, epithelioid histiocytes and giant cells, subdural hemorrhage caused by disseminated fungal infection, severe acute inflammatory infiltration (Picture 3-4). 


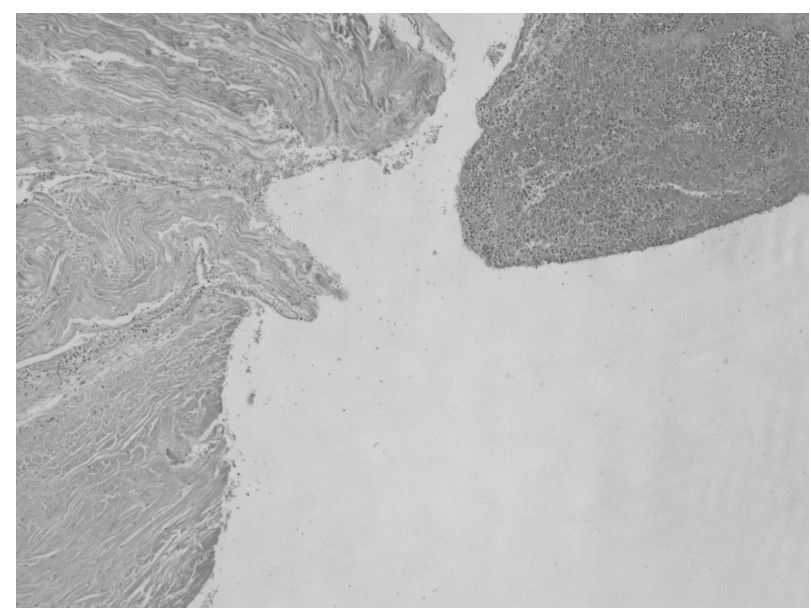

Picture 3. Hemorrhages on dura mater itself and subdural cavity (HE x4).

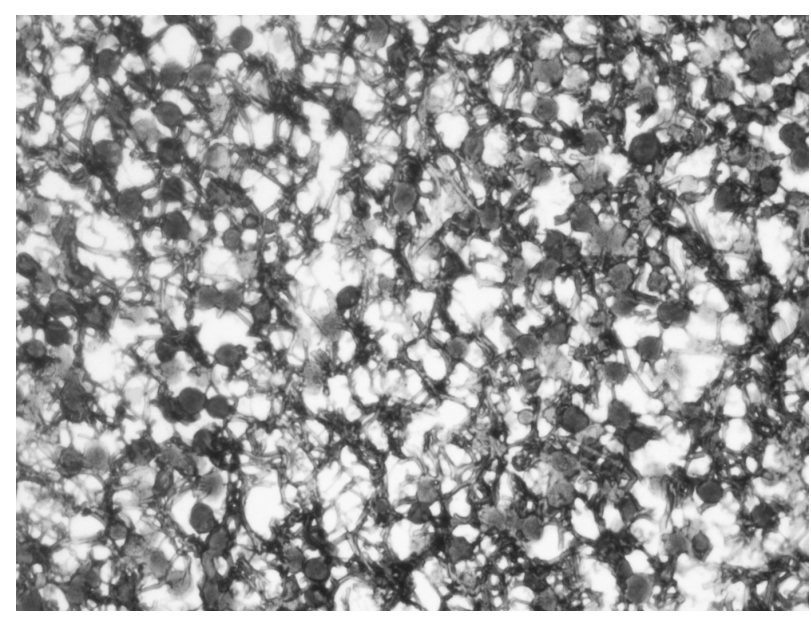

Picture 4. Fungal hyphae and spores in subdural hemorrhage (Methenamine Silver x40)

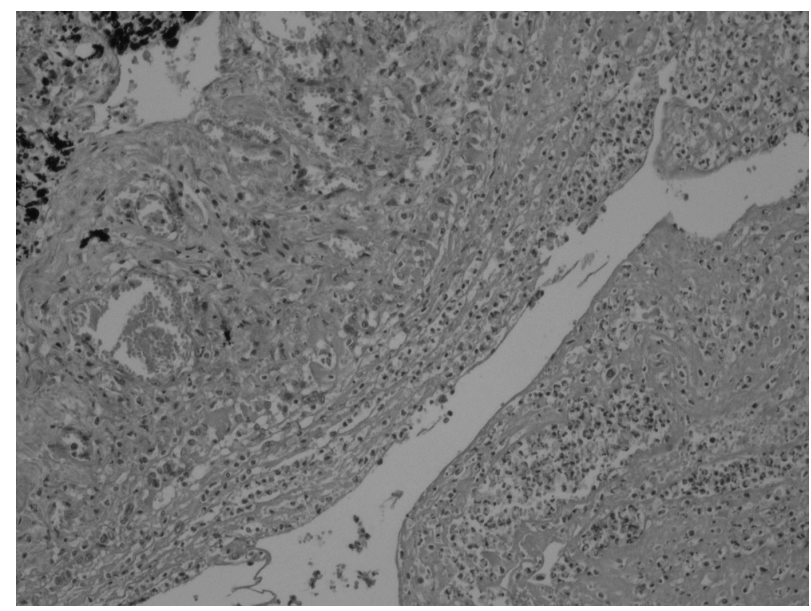

Picture 5. Acute fibrinous inflammatory infiltration in Visceral Pleura (HE x10).
Lungs; Acute inflammatory reaction in focal fields of the neighborhood of pleura in the right lung, intraalveolar edema, heart failure cells, focal severe fresh hemorrhages, obvious emphysematous changes, alveolar collapse specially at fields of the neighborhood of pleura, histopathological findings on walls of vessels which are considered to be caused by pulmonary hypertension, Grade II fat and bone marrow embolism, terminal food aspiration, congestion and anthracosis.

Parietal pleura (right); Acute fibrinous pleuritis (Picture 5).

A lymph node which obtained from hilus; Reactive hyperplasia, sinusal histiocytosis, anthracosis.

Diaphragma; Acute severe necrotic fibrinous inflammatory infiltration, dense fresh and old hemorrhagic fields (Picture 6).

Myocardium; Congestion and dilatation in the vessels, fibrosis in the interstitial and perivascular fields, hyperchromasia and enlarging at the nuclei of myocytes, irregular nuclear membrane.

Papillary muscle; Fibrosis in the interstitial fields, hyperchromasia and enlarging at the nuclei of myocytes, irregular nuclear membrane.

Visceral pericardium; Neutrophil-rich necrotic debris and fibrin deposition covering the entire visceral pericardium.

Parietal pericardium; Acute fibrinous pericarditis, focal thickening (Picture 7).

Kidney; Lymphocyte-rich inflammatory infiltration in stroma, tubular colloid like substance accumulation in some places, sclerosis in some glomeruli, mild chronic interstitial nephritis associated with congestion and dilation at the vessels.

Peritoneum and omentum majus; Acute necrotic fibrinous inflammatory infiltration (Picture 8,9).

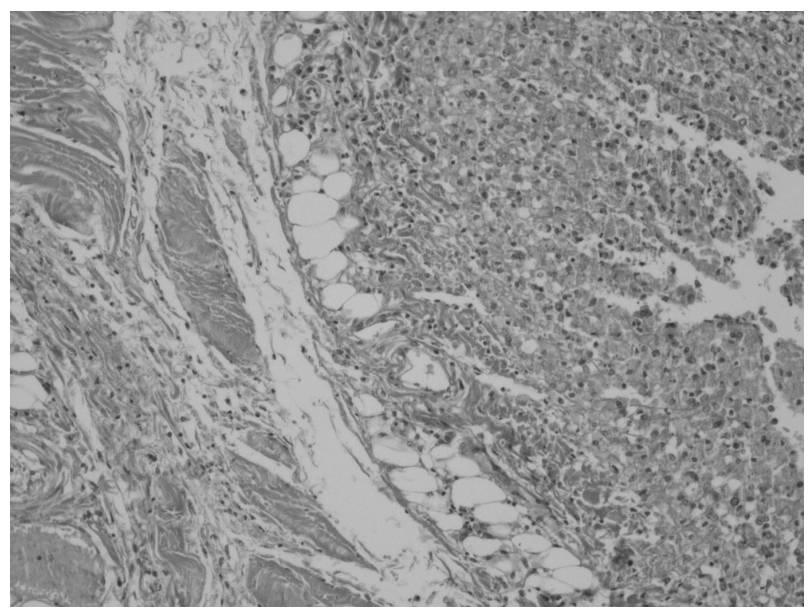

Picture 6. Acute fibrinous inflammatory infiltration on Diaphragma (HE x10) 


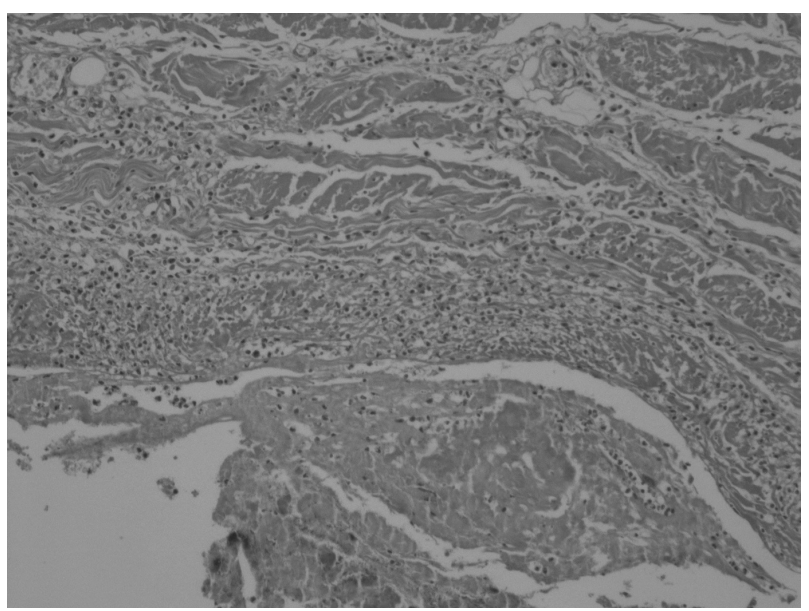

Picture 7. Acute fibrinous inflammatory infiltration at Parietal Pericardium (HE x10).

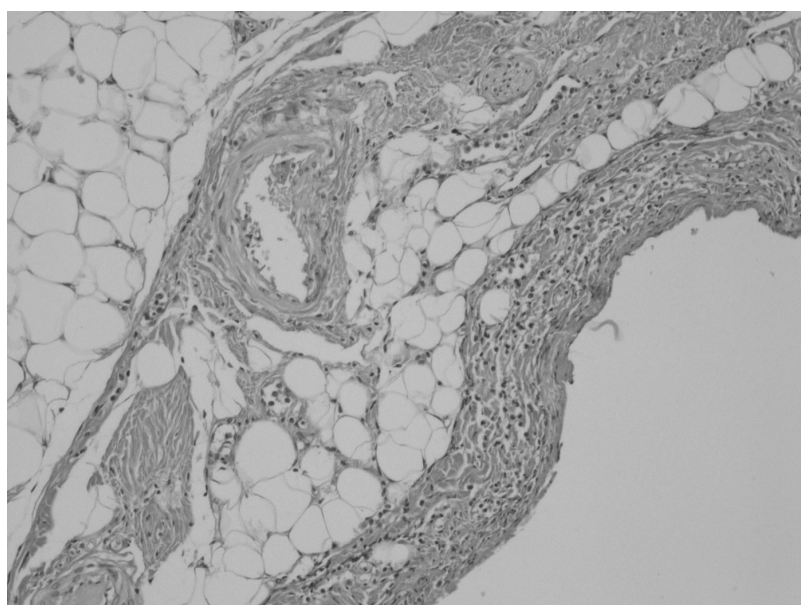

Picture 8. Acute fibrinous inflammatory infiltration in Parietal Peritoneum (HE x10).

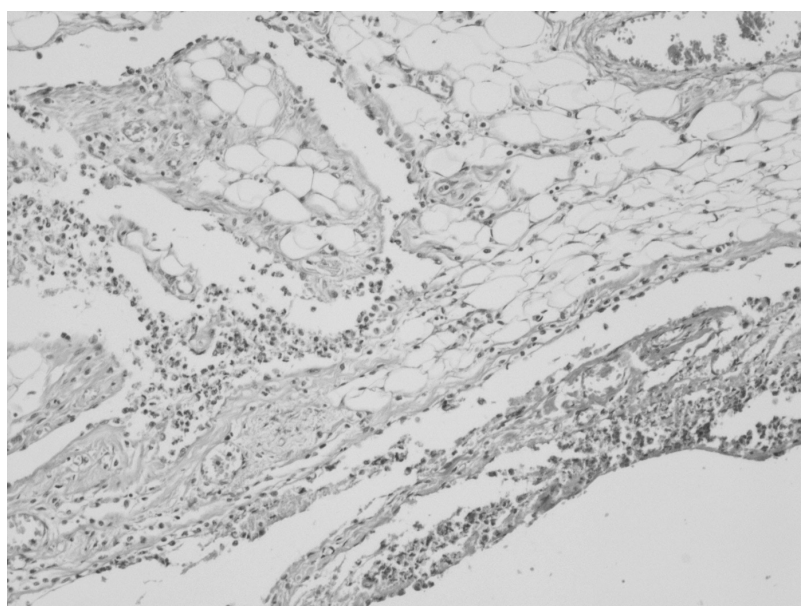

Picture 9. Acute fibrinous inflammatory infiltration in Omentum Majus (HE x10)

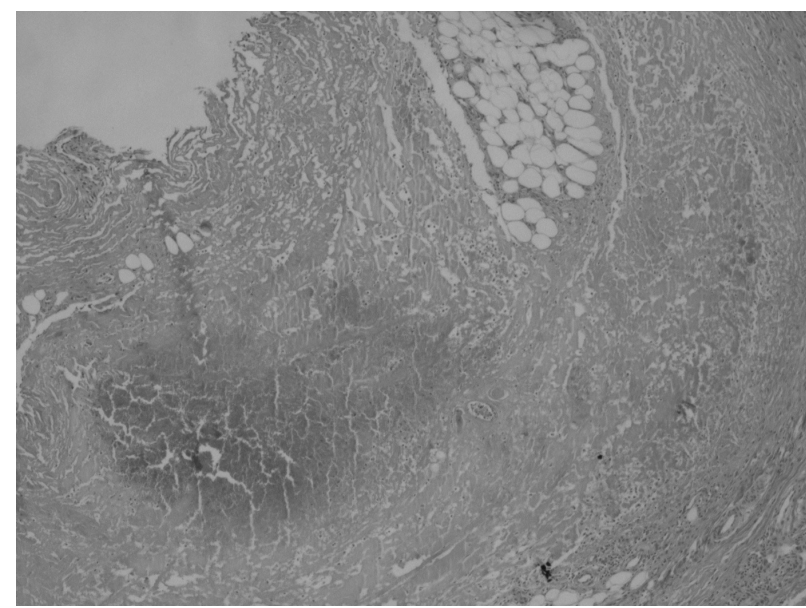

Picture 10. Bled necrotic field between mature adipose tissue which was well outlined and it was enriched by neutrophilic leukocytes in deeper dermis at sections taken from skin tissue of right forearm ( $\mathrm{HE} \mathrm{x} 4)$.

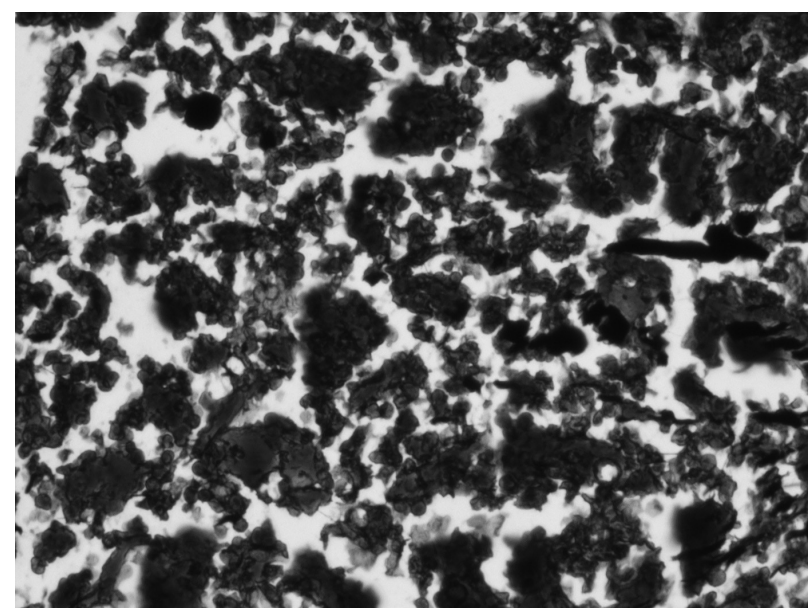

Picture 11. Fungal spores which are seen in bleeding necrotic tissue at sections taken from skin tissue of right forearm (Methenamine Silver x40).

Skin tissue which was obtained from right forearm; Cutaneous fungal infection (Picture 10-11).

Epicrisis: The case can be considered as disseminated fungal infection caused by different types of causative agents and sepsis depending on it, because of subdural hemorrhage, severe acute inflammatory infiltration in dura mater, several branching hyphae, fungal thrombi in the vessels and acute necrotic inflammation in the peritoneum, omentum majus, diaphragm, pericardium, pleura, lungs in association with the neutrophils and fungal spores which are seen in the lumens of vessels, fungal structures in spore form which are present in the skin lesions in papillonodular form. 


\subsection{Toxicological analysis}

Blood sample; $1136 \mathrm{ng} / \mathrm{ml}$ Codeine and $21820 \mathrm{ng} / \mathrm{ml}$ Morphine were determined as Opiates, besides another pharmaceutical active substance meconin was detected.

Urinalysis; The metabolites of codeine and heroin which are in opiate group, 6-monoacethyl morphine and morphine, pharmaceutical active substance papaverine and $10 \mathrm{mg} / \mathrm{dl}$ ethyl alcohol were determined.

\section{Discussion and Conclusion}

Intravenous illicit drug use, long-term continuous heroin usage, cocaine and amphetamine usage, and long-term continuous cannabis usage (for Turkish regulation) are defined as High Risk Drug Usage (HRDU). In Turkish Republic, it is stated that 648 drug abuse related deaths (direct 232 , indirect 416) occurred in 2013. It is stated that even if the outcomes are indicated not to be credible both because of used method and variations of data resources, total case of HRDU is calculated as 100621. According to the annual report of TUBIM, it is stated that in a research which was carried on with the participation of 8145 households from 25 cities, proportion of narcotic drugs usage at least once (lifelong drug use prevalence) is found to be $2,7 \%$ for 15 64 age group in 2011 (2).

Almost all illicit drug users are subjected to medicolegal autopsy, due to suspected unnatural death, however after the autopsy, $16-22 \%$ of cases have been determined to be caused by natural causes of death (3). In reality, identifying differences and using some common terms such as internal causes or selection of specific cases for researches, the causes of death drug users, prevalence of infectious agents and consequently the incidence of fungal infections-related information cannot be reliably obtained.

However, among illicit drug users the micro-pathogens can lead to infection easily, due to bad lifestyle factors, contamination of used drugs or equipment. In these individuals, infectious agents can directly affect the immune system (such as HIV), where it can also commonly cause endocarditis lung diseases and abscesses in different parts of the body, cellulitis, hepatitis A, B, C, sexually transmitted diseases and diseases of the musculoskeletal system (6). In addition to these, substances such as cocaine, opiates, alcohol, and cannabis can cause immunosuppression either via immunity responsible receptors or by reducing the antibody response in the cells and facilitate the development and spread of infection $(6,7,8)$. Inabo reported the decrease in the death rate from infection in AIDS patients by the discontinuation of substance use, and this situation has been accepted as an indicator of adverse effects on the immune system of illicit drug usage (6).
Between 2008 and 2013, Dignani carried out a research comparing the autopsy statistics of 11 researches and he stated that the incidence of common fungal infection of the population is $4,2-5 \%$ of autopsies and the most common ( $45-46 \%$ in all common fungal infections) causative agents are Aspergillus and Aspergillus-like organisms, followed by Candida (28-37\%), Cryptococcus species (4-19\%) and mucormycosis (2.6-8.3\%) (9). He has noted that a common fungal infection was observed in $25 \%$ autopsy cases with oncho-hematological diseases, in $24 \%$ autopsy cases with stem cell transplants, in $18 \%$ of autopsy cases of AIDS patients.

According to the article of Dignani, the most common 2 fungus species in the first two groups similar to the overall population, Aspergillus and Aspergillus-like organisms (55.5\% and $66.5 \%$, respectively) and Candida species ( $27.5 \%$ and $28.5 \%$, respectively) have higher proportions, but mucormycosis are often seen as the third frequency ( $6 \%$ and $12.5 \%$, respectively). In cases with AIDS, Jirovecii pneumocystis (45\%) has been the most observed fungus and it is followed by Aspergillus (29\%), Cryptococcus (22\%) and Candida (5\%) species (9).

Fungal infections are often slow in progress and also blood and other microbiological cultures might be negative. Therefore, clinical manifestations are often disguised and nonspecific (10). Microbiological examinations are not performed at the morgue department, so we couldn't have the possibility to identify the fungus species. In the case, when heart involvement characterized with enriched fibrin, skin and other organ findings are evaluated in together, it can be considered that the pathogenic agent is either Aspergillus or Aspergillus-like organisms. In infective heart involvement with Aspergillus-like organisms, neovascularization, granulomatous inflammation and calcifications are histopathologically distinctive symptoms. Published reports demonstrated that the pathogenic agent often cannot be seen (5) and thrombosed veins with hyphae infiltration and acute inflammatory infiltration are often seen as histopathological findings in infected organs (11).

However, in skin involvement associated with fungal infections, diagnostic findings are macroscopically papule, nodule, plaque appearance and histopathologically granulomatous inflammation, pseudoepitheliomatous hyperplasia, non-granulomatous perivascular and interstitial inflammation, vasculitis of small vessels and necrosis (12).

In the case, especially in dura sections, branching of fungal hyphae seen inside and outside of vein, thrombus formations composed of erythrocyte and fibrin and intense inflammatory cell infiltration at most prevalent on cardiac and pericardiac sections, omentum, pleura, 
peritoneum sections are found to be in accordance with the findings given by the references. Extensive fibrin and neutrophil-rich necrotic debris accumulation, which make the tissue to appear velvety are remarkable and compatible with the inflammatory process caused by widespread systemic infection.

In autopsy cases accompanied with the remarkable findings of systemic infection or a history of illicit substance abuse, the autopsy personnel is exposed to a high risk of infections caused by large number of previously known or undetermined micro-pathogens (13). It is important that the type of infectious agent to manage autopsy. Even though in most of the cases, autopsy personnel are not informed during decedent's delivery, biosecurity measures should be taken in terms of the autopsy environment, autopsy technique and protective clothing of personnel, depending on factors that may vary and they are defined by the rules of universal validity (13-15). At least surgical cap (or bonnet), FFP2 or FFP3 mask according to the suspected causative agent, gloves and a waterproof apron that covers the arms and face barrier and eye protection, protective footwear such as boots or waterproof personal protective equipment must be used (14). Personnel who have an open or fresh wound or immune system disorder should not be deployed in the autopsy (13, 14). To prevent the contact with causative agents having high risk of contamination through blood or tissue such as HIV, Prion it is also necessary to wear special protective clothes and gloves which are resistant to cut. The direction of flow of the ventilation in a way that protects the team should be towards down and bottom, and suction channels should be placed close to the base $(14,16)$.

The autopsy team must be regularly trained both theoretically and practically about infection control and prevention, selection and use of safety equipment, cleaning, disinfection and sterilization of equipment and autopsy room.

\section{References}

1. United Nations Office on Drugs and Crime (UNODC). World Drug Report 2014. United Nations Publication, New York, 2014:3, 6.

2. Turkish Monitoring Center For Drugs and Drug Addiction (TUBİM). National Report of EMCDDA, 2013. KOM Publishing, 2013:95.

3. Jönsson AK, Holmgren P, Druid H, Ahlner J. Cause of death and drug use pattern in deceased drug addicts in Sweden,
2002-2003. Forensic Science International, 2007;169:101107. doi: 10.1016/j.forsciint.2006.08.002

4. World Health Organization. Guidance on prevention of viral hepatitis $\mathrm{B}$ and $\mathrm{C}$ among people who inject drugs. WHO Press, Genova, 2012:13

5. Thiene G, Basso C. Pathology and pathogenesis of infective endocarditis in native heart valves. Cardiovascular Pathology, 2006;15:256-263. doi: 10.1016/j.carpath.2006.05.009

6. Inabo HI. The relationship between drug abuse and microbial infections. African Journal of Biotechnology, 2005;13 (4):1588-1590.

7. Cabral GA, Pettit DAD. Drugs and immunity: cannabinoids and their role in decreased resistance to infectious disease. Journal of Neuroimmunology, 1998;83:116-123. doi: 10.1016/S0165-5728(97)00227-0

8. Neri S, Bruno CM, Pulvirenti D, Malaguarnera M, Italiano $\mathrm{C}$, Mauceri B et al. Randomized clinical trial to compare the effects of methadone and buprenorphine on the immune system in drug abusers. Psychopharmacology, 2005;179:700 704. doi: 10.1007/s00213-005-2239-x

9. Dignani MC. Epidemiology of invasive fungal diseases on the basis of autopsy reports. F1000 Prime Reports, 2014;6:81. doi:10.12703/P6-81 doi: 10.12703/P6-81

10. Chinena K, Tokudab Y, Sakamotoa A, Fujiokaa Y. Fungal infections of the heart: A clinicopathologic study of 50 autopsy cases. Pathology - Research and Practice, 2007;203:705-715. doi:10.1016/j.prp.2007.06.008

11. Ohya İ, Bunai Y, Tsujinaka M, Akaza K, Nakamura I. Fatal Aspergillus pancarditis after incompatible blood transfusion intended to be an autologous blood transfusion. Legal Medicine, 2000;13:246-251. doi: 10.1016/S13446223(01)00037-2

12. Santiago TMG, Pritt B, Gibson L E, Comfere N I. Diagnosis of deep cutaneous fungal infections: Correlation between skin tissue culture and histopathology. Journal of American Academy of Dermatology, 2014;71:293-301. doi: 10.1016/j.jaad.2014.03.042

13. Hardin NJ, Infection control at autopsy: a guide for pathologists and autopsy personel. Current Diagnostic Pathology, 2000;6: 75-83. doi: 10.1054/cdip.2000.0021

14. Mazuchowski EL, Meier PA. The Modern Autopsy: What to do if infection is suspected. Archives of Medical Research, 2005;36:713-723. doi: 10.1016/j.arcmed.2005.04.006

15. Wighton GK, Kuhlencordh A, RolSbach K, Fischer G. Bone-dust in autopsies: Reduction of spreading. Forensic Science International, 1996;83:95-103. doi: 10.1016/ S0379-0738(96)02020-8

16. Centers For Disease Control and Prevention. Interim Guidance for Autopsy and Safe Handling of Human Remains of Monkeypox Patients, 2003. [cited 2016 Jan 1]. Available from: https://www.cdc.gov/poxvirus/monkeypox/index. html Last Accessed: 2017-08-04. 